\title{
Lightweight Brick Or M-Panel? Surabaya Expert View
}

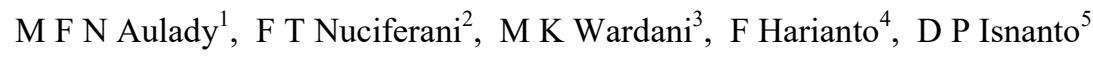 \\ Department of Civil Engineering, Institut Teknologi Adhi Tama Surabaya, Surabaya, \\ Indonesia ${ }^{1,2,3,4}$ \\ Graduate Student of Department of Civil Engineering, Institut Teknologi Adhi Tama Surabaya, \\ Surabaya, Indonesia ${ }^{5}$ \\ \{mohamadaulady@itats.ac.id $\left.{ }^{1}\right\}$
}

\begin{abstract}
This paper is to assist a new project manager who has a dilemma when has to determine material partition. In this research, we advantage two material between lightweight brick and M-panel. We conduct StrengthWeakness Opportunity and Treat analysis (SWOT analysis) to solve this dilemma. We ask the expert about Strength Weakness Opportunity and Treat for each material. Afterward, we ask the expert to give a score and do weighting for fair analysis. The result indicates that M-panel has good strength where this material is quick installation compared with lightweight brick, although only can transport with a heavy truck. And for the future opportunity, M-panel as eco-friendly material has a good chance even though the waste is difficult to handle.
\end{abstract}

Keywords: SWOT Analysis, Dilemma, M-Panel

\section{Introduction}

Shopping center in Indonesia is increasing as well the economic growth [1]-[4]. Recorded in 2014, The capital city of Indonesia has more than130 shopping centers[2] and 22 in 2017 for the second big city in Indonesia, Surabaya[4]. The rapid growth of shopping center indicates that Shopping center in Indonesia is a significant investment, so it must construct apace and the investor will get return dissipated too. To assure the advance of the shopping center are hasty, one of the crucial things is about making a dissolute decision[5], [6]. We need to make some decision when there are dilemmas. Dilemmas for construct shopping center can emerge at every stage, from choosing the location of a new construction project, through the step of making plans and designs until selecting technologies or materials[7]. Making a faithful decision are not comfortable moreover for a less experienced project manager. The Project manager has to make a simple analysis to get a better decision. Otherwise, they will get a lousy timing decision.

There are many decision support methods, which can help to solve a dilemma; one of them is SWOT analysis. SWOT - an acronym of strengths, weaknesses, opportunities, and threats is a structured planning method that evaluates the internal and external factors that are favorable or not in a project[8]. A SWOT analysis is already used to solve many dilemmas in any discipline, such as Business and Management [9]-[11], Industrial engineering [12]-[14] and also computer science[15]-[17]. This indicates that SWOT analysis is robust and adaptive in many dilemma situations. This paper aims to solve the dilemma problem in civil 
engineering problem. We will use SWOT analysis to solve dilemma problem into partition determination. The determination is between lightweight bricks and exposed fastener panel system type "M" (M-Panel). We ask the expert about the strength, weakness, opportunity, and threat for each partition material - furthermore we using SWOT matrix to analyze and make a decision among them.

Also, we choose Surabaya expert; because many projects in Surabaya are built by that material, it means many experts have already done with this dilemma. This research is intended to solve their dilemma between lightweight bricks or M-Panel for less experienced project manager so that they can make the right decision.

\section{Method}

To solve the dilemma between lightweight bricks and M-panel, we conduct expert who has three years' minimum experience to install both materials. We ask the expert about strength, weakness, opportunity, and threat among this material. Table 1 is an interview result for lightweight bricks SWOT. The expert opinion indicates that there six strength for thin bricks and four Opportunity. One of the weakness for lightweight blocks are to install lightweight bricks the manager has to assist foremen to overseas the worker. Which is the manager needs more money to install it? Other treats about lightweight blocks are the waste after installation are also high, which is the manager has to more care to handle this.

Table 1.The Strength and Weakness of Lightweight Bricks

\begin{tabular}{|c|c|}
\hline Strength & Weakness \\
\hline 1. Less worker & 1. the cost is more twice if added more worker. \\
\hline 2. No need special skills & 2. Need foreman to oversee the worker \\
\hline $\begin{array}{l}\text { 3. Can use for narrow space } \\
\text { area }\end{array}$ & $\begin{array}{l}\text { 3. Need time and cost to transport from fabrication } \\
\text { place }\end{array}$ \\
\hline 4. Easy Installation & 4. Need unique items to install it \\
\hline 5. Low-cost installation & 5. Price depends on economic situations \\
\hline 6. Low risk & 6. Need more space for worker \\
\hline
\end{tabular}

Table 2.The Opportunity and Treat of Lightweight Bricks

Opportunity Treat

$\begin{array}{lll}\text { 1. The value of partition installation is an } & \begin{array}{l}\text { 1. Waste installation are high } \\ \text { increase }\end{array} & \text { 2. Need movement process before } \\ \text { 2. Reduce unemployment } & \text { 3. Need special packing for transportation } \\ \text { 3. The material is eco-friendly } & \text { 4. Cant recycle if broke before use it }\end{array}$

In other hands for M-Panel, the expert suggest there six Strength and weakness. One of the opportunities about M-panel is, this material is eco-friendly, but the waste is difficult to handle as shown in Table 2. To Install M-panel, the project manager has to spend more money, because the worker is limited due to the specialty skill and the certificate that they provide. 
Table 3.The Strength and Weakness of M-Panel

\begin{tabular}{|c|c|}
\hline Strength & Weakness \\
\hline $\begin{array}{l}\text { 1. Need a particular skill worker, which the result is } \\
\text { more goodly }\end{array}$ & $\begin{array}{l}\text { 1. The worker wants to incentive } \\
\text { due to the specialty skills }\end{array}$ \\
\hline 2. The worker should have more experience to & 2. High-risk installation \\
\hline handle it due to specialty skills & 3. Need expert certificate for \\
\hline $\begin{array}{l}\text { 3. The worker has to use Personal Protective } \\
\text { Equipment, which is safer for the worker. }\end{array}$ & $\begin{array}{l}\text { worker } \\
\text { 4. }\end{array}$ \\
\hline 4. Time installation is short & 5. Only can transport by heavy \\
\hline 5. Shorten the schedule & truck \\
\hline 6. Supporting Building Structures & $\begin{array}{l}\text { 6. Can install in one side of } \\
\text { partition side }\end{array}$ \\
\hline
\end{tabular}

Table 4.The Opportunity and Treat of M-Panel

\begin{tabular}{lll}
\hline \multicolumn{1}{c}{ Opportunity } & \multicolumn{1}{c}{ Treat } \\
\hline 1. This material is very new in the construction & 1. Need special workers \\
& project & 2. The material uses are still low \\
2. Have special abilities in the field of walls pairs & 3. The waste is difficult to handle \\
3. Eco-friendly material & 4. The size is the height \\
4. Easy treatment & 5. Rarely in small construction \\
5. Can use for the main structure & & store \\
6. Can use all cement type for installation &
\end{tabular}

Every expert has their opinion about strength, weakness, opportunity, and threat. To carry this situation, we ask the respondent to give a weighting score for each variable. We merge all opinion from all expert and return to them, and they have filled the variable with scale one to five. One for disagree and five for agree. Furthermore, we average the score and implementation to the SWOT matrix. We also analysis the time and price installation between them to make a complete comparison.

\section{Result and discussion}

First, we calculate the time and value for lightweight masonry and M-Panel installation. We use two different thickness of thin brick and M-Panel. For a lightweight block with $10 \mathrm{~cm}$ thickness, the cost for installation is 133.500 IDR or around 9.21 USD ( 1 USD = 14.540 IDR) and 10.10 USD for $12 \mathrm{~cm}$ Thickness per $\mathrm{m} 3$. The average installation time is about 20 minute for both thicknesses. Whereas for M-Panel, The cost is 14.24 USD for $10 \mathrm{~cm}$ Thickness and 15.45 USD for $12 \mathrm{~cm}$ thickness per $\mathrm{m} 3$. The cost of M-panel installation is more costly compared with a lightweight brick. But for time installation, M-Panel is more debauched. The standard setup is about 10 minutes ahead compare with a lightweight block for $\mathrm{m} 3$. In other words, M-Panel is dissipated than thin brick, but it more expensive. As mention, M-panel is useful to time installation, but it high-priced. This analysis is baffling for the decision maker. But it can use for the second opinion. In this section, we review the material using the SWOT method. The result is indicated in Table 3. 
Table 5. SWOT Total Scores

\begin{tabular}{|c|c|c|c|}
\hline \multirow{2}{*}{ No } & \multirow{2}{*}{ Qualification } & \multicolumn{2}{|c|}{ Total Score } \\
\hline & & Lightweight brick & M-Panel \\
\hline 1 & Strength & 1.80 & 1.84 \\
\hline 2 & Weakness & -1.51 & -1.36 \\
\hline 3 & Opportunity & 0.82 & 1.56 \\
\hline 4 & Threat & -1.16 & -1.50 \\
\hline
\end{tabular}

The total score from respondent for strength variable for Lightweight brick and M-panel are closed. The quiet different is a score in Opportunity. The lightweight brisk are very low. Aside From scale one to five, both of material score is low. Furthermore, we applied the score to SWOT matrix to get a more clear understanding. Both materials are inclined in quadrant one where the Opportunity and the strength are dominant. This result indicates that both elements have good power and future convenient to use in a construction project. The Strength and opportunity of the material can be accepted of the weakness and Treat.

As the SWOT result, both materials have a more positive value. The expert accepts the weakness and treats for the stuff. The strength of low-cost installation reaches the highest average score from the expert. This variable can cover the fault of the cost are more twice if added more worker. For M-Panel Time Installation are the high value can cover. Only can transport by heavy truck weakness variable. This indicates the transportation is not a priority for use this material; the concern is about time installation. Both article also has an excellent opportunity in the future as partition material. For M-Panel eco-friendly material are an excellent future opportunity. In other hands, The value of wall pair is a unique opportunity for lightweight brick. On the other side by using lightweight block, partition installation no longer accepted as not necessary work. Except for the treatment for light brick is there many waste part after installation. Merely for M-panel challenging to manage the waste are testing in the future.

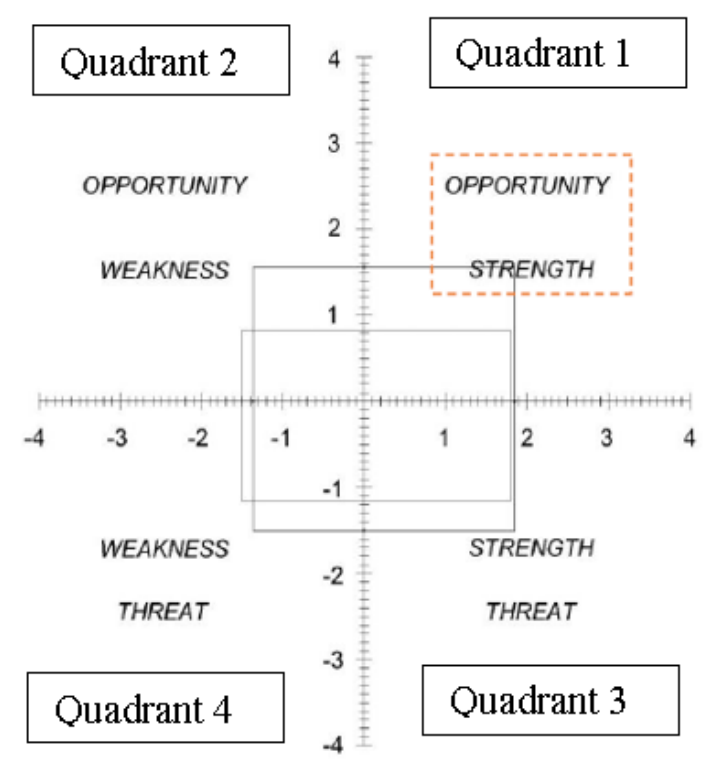




\section{Figure 1.SWOT Matrix}

As the SWOT result, both materials have a more positive value. The expert accepts the weakness and treats for the stuff. The strength of low-cost installation reaches the highest average score from the expert. This variable can cover the fault of the cost are more twice if added more worker. For M-Panel Time Installation are the high value can cover, only can transport by heavy truck weakness variable. This indicates the transportation is not a priority for use this material; the concern is about time installation. Both stuff also has an excellent opportunity in the future as partition material. For M-Panel eco-friendly material are an excellent future opportunity. In other hands, The value of wall pair is a unique opportunity for lightweight brick. On the other side by using lightweight block, partition installation no longer accepted as not necessary work. Except for the treatment for light brick is there many waste part after installation. Merely for M-panel challenging to manage the waste are testing in the future

\section{Conclusion}

This aim for this research is to help new project manager in a construction project if they have a dilemma between light brick or M-panel for their partition. We clear up this dilemma by using SWOT analysis. The result indicates that M-panel are more reliable for separation instead the risk is high and also the worker has to certificated owned. But the not much different cost with lightweight brick and faithful installation make expert choose this material.

Both material also has an excellent opportunity in the future as partition material. For MPanel eco-friendly material are an excellent future opportunity. In other hands, The value of wall pair is a unique opportunity for lightweight brick. On the other side by using lightweight block, partition installation no longer accepted as not necessary work. Except for the treatment for light brick is there many waste part after installation. Merely for M-panel challenging to manage the waste are testing in the future.

\section{References}

[1] R. Suryadjaja, "Jakarta's tourism evolution: Shopping center as urban tourism," presented at the 6th Conference of the International Forum on Urbanism (IFoU): TOURBANISM, Barcelona, Spain, 2012, pp. 1-9.

[2] Widiyani and H. J. Timmermans, "Evolutionary patterns in Indonesian shopping centers: The case of Jakarta," presented at the 18th Annual European Real Estate Society Conference in Eindhoven, the Netherlands, Eindhoven, Netherlands, 2011, p. 14.

[3] A. Marsha, "The Impact of Plaza Indonesia Shopping Mall's Attributes toward Customers' Satisfaction," iBuss Management, vol. 3, no. 2, pp. 49-57, 2015.

[4] M. A. Yaqin and S. Purwanita, "Increasing customer intention to visit Mall in Surabaya- An architectural perspective," in UIA 2017 Seoul Proceedings, Seoul, South Korea, 2017, pp. 1-6.

[5] M. Kownatzki, "The Speed of atrategic Decision-making and The impact of corporate involment at the SBU-level," University of St. Gallen, Switzerland, 2002.

[6] K. M. Eisenhardt, "Making Fast Strategic Decisions in High-Velocity Environments," p. 35 . 
[7] E. Szafranko, "Decision problems in management of construction projects," IOP Conference Series: Materials Science and Engineering, vol. 251, p. 012048, Oct. 2017.

[8] I. Streuli, J. Benard, J. Hugon-Rodin, C. Chapron, P. Santulli, and N. Pluchino, "Shedding light on the fertility preservation debate in women with endometriosis: a swot analysis," European Journal of Obstetrics \& Gynecology and Reproductive Biology, vol. 229, pp. 172-178, 2018.

[9] S. S. Lee and Y. K. Chung, "A study on development strategy of Korean hidden champion firm: Focus on SWOT/AHP technique utilizing the competitiveness index," Journal of International Entrepreneurship, Jun. 2018.

[10] Ž. Živković, D. Nikolić, M. Savić, P. Djordjević, and I. Mihajlović, "Prioritizing Strategic Goals in Higher Education Organizations by Using a SWOTPROMETHEE/GAIA-GDSS Model," Group Decision and Negotiation, vol. 26, no. 4, pp. 829-846, Jul. 2017.

[11] M. Tavana, M. A. Sodenkamp, and L. Suhl, "A soft multi-criteria decision analysis model with application to the European Union enlargement," Annals of Operations Research, vol. 181, no. 1, pp. 393-421, Dec. 2010.

[12] S. M. Arabzad, M. Ghorbani, J. Razmi, and H. Shirouyehzad, "Employing fuzzy TOPSIS and SWOT for supplier selection and order allocation problem," The International Journal of Advanced Manufacturing Technology, vol. 76, no. 5, pp. 803-818, Feb. 2015.

[13] M. Moghaddaszadeh, A. H. Sarfaraz, A. R. Komijan, and A. A. Shojaie, "An integration of SWOT and factor analysis to determining and prioritizing strategies: case study of a Persian food industry," International Journal of System Assurance Engineering and Management, vol. 6, no. 3, pp. 297-303, Sep. 2015.

[14] N. N. Man'kina, E. A. Lysenko, and S. E. Lysenko, "Results of steam-water-oxygen treatment of boiler units for the 300-MW power-generating sets at the Novocherkassk State Area Power Station," Power Technology and Engineering, vol. 41, no. 2, pp. 111-113, Mar. 2007.

[15] A. Maté, J. Trujillo, and J. Mylopoulos, "Stress Testing Strategic Goals with SWOT Analysis," in Conceptual Modeling, 2015, pp. 65-78.

[16] A. Davidson, J. de La Puente Martinez, and M. Huber, "A SWOT Analysis of Virtual Laboratories for Security Education," in Information Assurance and Security Education and Training, 2013, pp. 233-240.

[17] S. Liangtao and C. Gang, "SWOT Analysis of E-Commerce Development in Yunnan Province," in Innovative Computing and Information, 2011, pp. 492-499. 